\title{
Robert Francis Byrnes, 1917-1997
}

Robert F. Byrnes died of congenital heart disease on 19 June 1997, while attending a family reunion in North Carolina. Many readers of this journal and members of its sponsor, the American Association for the Advancement of Slavic Studies (AAASS), will remember him as a widely published scholar, the founder and chief architect of Indiana University's famous Russian and East European Institute, the author of major works on Konstantin Pobedonostsev and Vasilii Kliuchevskii and, among other things, a past president of the AAASS. They may be interested to know that he was also the secretary of the body (the Joint Committee on Slavic Studies of the American Council of Learned Societies and the Social Science Research Council) that decided in 1960 to convert the AAASS into a membership organization and that he served on the editorial board of Slavic Review from 1956 to 1974, perhaps longer than anyone else to date.

How Byrnes got his start is told in a memoir he wrote for Russian History in 1988. His family lived in Waterville, New York, near Utica. He was the fifth of twelve children born to Pauline Albecker and Michael Joseph Byrnes, a baker. Neither of his parents had finished high school, but they valued knowledge and read widely. Along with playing basketball, Bob hung out at the public library. In high school he was already reading Fedor Dostoevskii and William Henry Chamberlin.

Bob left New York state for the first time when he attended Amherst College, where he won scholarships for all of his four years. There Laurence B. Packard, whom Bob called the most effective teacher of history he ever met, stimulated his interest in Russia and in the writings of Kliuchevskii. In 1939, Packard then steered him to Harvard, where he won fellowships for four years of graduate study. Bob had hoped to focus on Russian history, but Michael Karpovich was still teaching only undergrad. uate courses, including a one-year survey of Russia. So, while Bob took that survey and also studied basic Russian with Samuel H. Cross, he did his Ph.D. in French history. It was William L. Langer who pointed him toward his dissertation topic, on antiSemitism in France and the background of the Dreyfus Affair. Meanwhile Bob had married Eleanor $F$. Jewell, whom he had been dating since his junior year at Amherst. She was his partner from then on, not just in raising their seven children but in every aspect of his career, including his research and editing. On 6 June 1997, they celebrated their fifty.fifth anniversary.

By mid.1943 Bob had virtually completed his doctoral degree. He qualified for wartime assignments in Washington, first with the Foreign Economic Administration and then with the Special Branch of Military Intelligence, where he studied the Japanese electronics industry for targeting purposes. Released in August 1945, he moved immediately into teaching European and Russian history, first at Swarthmore and then at Rutgers.

Early in 1948, when Bob was already thirty and had a family to support, a letter from Geroid T. Robinson invited him to spend two years as a postdoctoral Senior Fellow in the five-discipline program at Columbia University's new Russian Institute. Bob said those years changed his life. I can testify that he and the other Senior Fellows enriched the Institute for the rest of us.

Hardly had he resumed teaching at Rutgers in 1950 when he faced another choice. War had come to Korea. Needing greater research capacity, the recently established Central Intelligence Agency (CIA) had set up an Office of National Estimates (ONE) under Langer. Langer invited Bob to become one of the fifteen junior members of the ONE. Bob served there from 1951 to 1954, and then in the CIA-funded MidEuropean Studies Center, where he became the director in 1955. He prized the stimulating debates and the objectivity he found within the research arm of the CIA. He felt it had been a mistake to attach to the CIA a covert or operations function.

Slavic Review 56, no. 4 (Winter 1997) 
In 1956 he became professor of history at Indiana University, recruited by President Herman B Wells, who had been fostering East European studies there since World War II. An East European Institute had been in existence there since 1952. Wells worked closely with Byrnes to set up a Russian and East European Institute, to add many new senior faculty specialists, to attract large foundation grants, and to fund graduate fellowships on an unprecedented scale. With Byrnes serving two terms as director, the Indiana Institute became a model area studies program in the 1960s and 1970s. It often ranked first in the United States among comparable centers, and In. diana became one of the main producers of professionals in our field.

Byrnes's many other accomplishments and honors help to explain why Wells eulogized him as "one of the men who made IU great." He chaired the Department of History. He earned the rank of Distinguished Professor of History. $\mathrm{He}$ won the Brown Derby Outstanding Teaching Award. He wrote his comprehensive studies of Pobedonostsev and Kliuchevskii along with five other large books and several shorter ones. He edited half a dozen volumes and supervised the editing of many more. His essays in books numbered over fifty. He published over one hundred journal articles. Always generous in responding to invitations, he delivered over four hundred scholarly lectures at conferences, government institutions, and colleges and universities, over seventy of which were in twenty-three different foreign countries. He was a consultant to many foundations and government bodies. He held offices in several pro. fessional organizations, including the Catholic History Association and the American Historical Association. He won fellowships from the American Council of Learned Societies and the Guggenheim, Rockefeller, and other foundations, including one at Princeton's Institute for Advanced Study. He sat on the boards of trustees of Boston College and Alverno College and received honorary doctorates from Amherst, Coe, and St. Mary's Colleges.

Bob knew how to use each minute. I recall once his saying that on the way over to Urbana by car from Bloomington to give a lecture, he had read a book and completed a review of it. He could do this because it was Eleanor who drove. Indeed, on their many automobile trips it was always Eleanor who drove, thereby enabling Bob to use the car as an office.

And yet he was no greasy grind. Harking back to his days as a high school firststringer, Bob was an enthusiastic rooter for Hoosier basketball, both at games and at practice. He loved to "coach" Coach Bobby Knight. After Bob's death, Knight announced that Bob's seat at the Assembly Hall now bore a plaque: "From 1971 to 1997, this seat was occupied by Robert F. Byrnes, an extraordinary teacher, patriot, and friend of the coach." So there will be a "Byrnes Chair" for Indiana basketballers as well as Byrnes Fellowships at Indiana's Russian and East European Institute.

Among my recollections of Byrnes, some of the clearest are from a week-long trip we took together in Poland in 1957 and from the 1960s when he was running the Inter-University Committee on Travel Grants (IUCTG, which later became the International Research and Exchanges Board). His playfulness and optimism were combined with a deep concern for human suffering and injustice. Remembering what it was like to be part of a small Catholic minority. Bob was always ready to help the underdog. Keenly aware that he had not been able to study Russian when young, to speak the language easily, or even to visit the USSR until he was almost forty, he fought hard to enable as many young scholars of the 1960 s as possible to have the opportunities that had been denied to him. Coming from a family he characterized as poor in the $1930 \mathrm{~s}$, he made the IUCTG watch its pennies. Disturbed by the breakup of marriages caused by lengthy separations, Bob stretched the funds so that spouses could accompany researchers. He could be hard on those he felt were not playing fair with spouses left at home, or with the IUCTG, or with our country.

Soon after the start of the IUCTG, Bob learned that representatives of the CIA were informally telling future exchangees of the CIA's interest in any information the exchangees saw fit to share with them after their return. Bob was determined to keep the exchange program independent and to protect individual scholars against the Soviet accusation that they were CIA agents. He went right to the top and persuaded 
the CIA's director to instruct all personnel to avoid contact with IUCTG researchers before their departure. Meanwhile, Bob told all IUCTG scholars to refuse to speak with CIA people before they left and to report any attempted approaches to his office. After one attempt reported the next year, to which Bob protested with what I recall as tactful fury, I believe the CIA kept its people in line. I cannot think of anyone who could have handled that problem better than Bob Byrnes.

RALPH T. Fisher, JR. University of Illinois, Urbana.Champaign November 1997 